\title{
Trapped in the Realm of the Body: Normative Bodily Practices in ESOL Pedagogy
}

Suhanthie Motha

This article examines processes of gender identity construction in the classrooms of two ESOL teachers living in their first year of teaching. Drawing from a year-long study of beginning teaching, the author explores the complex relationship among the physical body, language pedagogy, and socially constructed understandings of beauty, then goes on to problematize the pedagogical location of the body and ask how the gendered body can be mediated in classroom contexts. The article contrasts the two teachers' pedagogical approaches to the intricate work of locating the body in the ESOL classroom and discusses the range of possibilities available for the exploration, negotiation, and expression of gender identities in relation to the physical body.

Cet article porte sur la construction de l'identité de genre dans la salle de classe de deux enseignants d'anglais aux locuteurs d'autres langues (ESOL), pendant leur première année d'enseignement. Puisant dans une étude qui a porté sur les débuts de carrière d'enseignants et qui a duré un an, l'auteur porte son attention sur la relation complexe entre le corps, la pédagogie en langue seconde et les connaissances sur la beauté, telles que définies par la société. Par la suite, il explique la problématique de la place du corps dans la pédagogie et se demande comment le corps genré peut être médiatisé dans le contexte d'une salle de classe. L'article dresse une comparaison entre les approches qu'ont les enseignantes face à la place délicate et complexe qu'occupe le corps dans leur cours de langue. Finalement, on présente la gamme de possibilités sur les plans de l'exploration, la négociation et l'expression des identités de genre par rapport au corps.

\section{Introduction}

As researchers examine how teachers teach language, they are actually scrutinizing the multiple ways that identity-including gender identity-is represented and constructed in classrooms. As crossroads of multiple cultural and linguistic identities, ESOL classrooms allow a special perspective: they are sites where vastly divergent and mutable meanings of gender meet and are negotiated. In this article I examine processes of gender identity construction by drawing on the experiences of two beginning ESOL teachers, 
exploring the complex relationship among the physical body, language pedagogy, and socially constructed understandings of beauty.

Studies of language and gender to date have been important in highlighting how men and women use language differently (Lakoff, 1975; West \& Zimmerman, 1983; Pica, Young, \& Doughty, 1991; Oxford, 1995); how linguistic practices contribute to, or counteract, oppression (Cameron, 1990); the relationship between multilingualism and gender (Gal, 1978; Pavlenko Blackledge, Piller, \& Teutsch-Dwyer, 2001); how language learning is connected to gendered access to the public world (Goldstein, 1997; Kouritzan, 1999; Norton, 2000); and how discourse shapes and is shaped by gender (Sunderland \& Litosseliti, 2002). However, in the context of language pedagogy, the physical body and normative bodily practices have been notably absent from discussions of gender identity. Over the past two decades, sociologists, educational theorists, and scholars from other fields, influenced by postmodernism and feminist theory, have begun to challenge the conceptualization of humans as bodiless minds in interaction with each other and instead are examining how the body carries meanings that are crowded with social and historical relevance. Educators are examining the location of the body within school walls, and conversely, asking about the place schooling occupies in the body and the social meanings that schools and other institutions have inscribed on the body. Nonetheless, examination of the body has yet to gain currency in the TESOL discipline.

Exploration of specific local knowledges, referred to by Foucault (1978) as subject knowledges, have focused attention inward to the personal and the body. Foucault's (1981) discussion of the body was on concern about power in relation to social control of the body and sexuality. In 1984 Turner challenged the mind-body dualism of Cartesian thought and encouraged sociologists to consider how the body is socially constructed. Educators including hooks (1994) and Grumet (1998) theorized the social meanings written on the body and examined how to invite the body into learning spaces.

In the 1990s, feminist theorists, many of whom had previously worked determinedly to construct female bodies as transparent, allowed the body to materialize and began to look at its relationship with identity. The discourses surrounding the admission of the body into the theoretical arena are tentative and tinged with fear of essentialism, of once again reducing women to their physical selves. Butler (1990) shifts our focus from the actual gendered body to how the body is made to be gendered by the acts it performs in the construction of identity. For Butler there is no biologically based sex, only socially constructed gender. Her notion of performativity conceives the various acts that humans perform as inscribing the body with gender. Like Butler, Grosz (1994) critiques mind-body dualisms, calling instead for "em- 
bodied subjectivity" and "psychic corporeality," but unlike Butler she claims that gender is inevitably biologically rooted and predetermined.

What are the implications for ESOL classrooms of the body's current status in educational circles? In even a brief review of literature connecting TESOL and gender, sex role theory appears as preeminent (Oxford \& Green, 1995; Sunderland \& Litosseliti, 2002). Sex role theory, which critiques societal norms about behavioral expectations for men and women, has been important in advancing understandings of how gender oppression is actualized and maintained, and consequently how certain constructs are valued differently according to the gender with which they are most tightly associated. However, the essentialist underpinnings of sex role theory have contributed to a binary construction of gender and to the invisibility of gendered identity in the language classroom. For ESOL teachers, acknowledging the body is not a simple undertaking in the light of all its attendant baggage. Recognizing female students' bodies is particularly complicated, because once females are associated with their bodies, this connection can become indivisible, and they can become trapped in the realm of the body (Gallup, 1988). The time has come for an examination of how ESOL teachers can situate the body in their classrooms.

\section{Methodology}

In this article I discuss one thread of a larger, year-long study that examined the teaching lives of four female first-year teachers, asking about their meanings of identity, knowledge, and pedagogy in the context of learning to teach language. This current analysis compares two of the teachers' understandings of gender identity. First-year teachers Katie and Alexandra chose contrasting approaches to the challenge of locating their students' physical selves in their classrooms.

\section{Alexandra and Katie}

Alexandra and Katie were recent graduates of a master of education program in TESOL near a large metropolitan center in the Mid-Atlantic area of the United States. Both taught ESOL in the same suburban school system, and both were in their second semester of teaching when the study began. Alexandra was a middle school teacher, and Katie taught at the elementary level. Alexandra was born and raised in the United States and was white. She had lived in Japan for two years and was married to a Vietnamese man. Katie was born in Korea and adopted by an American family of German-Irish descent when she was four months old. She was fluent in Spanish and had lived in Spain and in Zimbabwe. Both teachers expressed a desire to support social justice and identified themselves as feminists. Research into questions of social and cultural identity had played a central role in both of their master's theses. My relationships with each of them extended back to two 
years before the study began. They had both been students in classes I had co-taught in their master's program. I had supported their seminar papers and had served as coordinator of their student teaching experiences.

My history with Katie and Alexandra had a bearing on my role as researcher. The question of how much a researcher may be affected by his or her own personal reactions to the study has been argued throughout history, but more hotly in recent decades. The supposition that objectivity is desirable is predicated on the existence of both an absolute truth and a path that leads if not directly to it, at least to within a stone's throw of it. The form of knowledge pursued in this study was neither detached nor objective. Rather, I sought meaning that was jointly constructed by the participants and me, and now with you the reader. Gilligan (1982) has suggested that connection, historically viewed as a pollutant in research, actually furthers our humanness by stimulating our recognition of responsibility for one another. She deplores situations where "the interconnections of the web are dissolved by the hierarchical ordering of relationships, when nets are portrayed as dangerous entrapments, impeding flight rather than protecting against fall (p. 49). In a complex, context-dependent study, connection can help us to paint a richer landscape.

\section{Theoretical Framework}

The theoretical framework for the study was influenced by critical pedagogy (Kanpol \& McLaren, 1995; hooks, 1994; Freire, 1974), feminist theory (Fine, 1992; Harding, 1987; Lather, 1991), and sociocultural theory (Vygotsky, 1978; Tharp \& Gallimore, 1988; Gee, 1991; Van Lier, 2000).

In this research I assume that meanings of gender are not passed cleanly and unidirectionally from teachers to students, but rather are co-constructed in communities of practice (Lave \& Wenger, 1998) through social interactions in the classroom as "individuals produce themselves (or are produced) as 'gendered' by habitually engaging in the social practices of a speech community that are symbolically and practically associated with masculinities or femininities or some combination thereof" (Erlich, 2001, p. 120). How far the students accept or reject new identities or even new constructions of gender is part of the negotiation of identities in ESOL classrooms. However, it would be naive and even misleading to ignore power relations in classrooms (Morgan, 1998). Although teachers do not singlehandedly define gender for their students, they have pedagogical power because teachers' dominance in the classroom is socially legitimized (Bourdieu, 1982). The negotiation of identities is, therefore, not carried out in a neutral context.

\section{Data Sources}

I learned from the teachers in a variety of ways: (a) afternoon teas every two to three weeks, with a six-week pause over winter break; (b) classroom 
observations (1-2 hours every week or two for each participant from October to December, then 2 hours every 3 or 4 weeks from January to March); (c) informal one-on-one interviews with the participants before the study began periodically throughout the year and after the school year closed; (d) informal e-mails and telephone conversations between the participants and myself; (e) lesson plans; (f) county curricula; (g) students' work; (h) discussions with students; and (i) discussions with other school faculty. I transcribed all the tapes myself.

\section{The Afternoon Teas}

Because the afternoon teas became my most important data source, I explain how they evolved and how they enriched this study methodologically. In the tradition of what Audre Lorde called early feminism's "kitchen table conversations," we gathered in my home after school every two or three weeks over the course of the school year to share tea and stories. The afternoon teas were initially two or three hours long, but gradually grew longer until they evolved into dinners that stretched late into the night. The afternoon teas had a special advantage: although observations are informative and real in a positivistic sense, they inevitably objectify participants because they are experienced and represented through the eyes of the observer or researcher. An inevitable tension arises when the person telling a story is not the person whose story is being told (Motha, 2002). The afternoon teas created a space especially for teachers' voices, which increased the teachers' degrees of authorship and authority in how I interpreted their teaching. Something about the afternoon teas helped to disrupt the traditional researcher-researched structures of power because the teachers chose which stories to tell and how to tell them.

\section{Data Analysis}

In response to Harding's (1987) call to rectify the androcentrism of research, I took steps designed to accentuate the qualities I believed were well represented by the afternoon tea data, including participant voice, participant power, and respect for the researcher-participant connection. I made modifications to commonly used research methods. I used constant comparative method (Strauss \& Corbin, 1997) as is popular in qualitative data analysis, starting with line-by-line analysis because it is likely to be the most generative (Glaser \& Strauss, 1967). However, I took a step designed to privilege the aftemoon tea transcriptions. I first coded data from the afternoon teas only in order to identify and then privilege the themes that were most prevalent in the dialogic context of the four teachers telling their own stories in community with each other and me. I then introduced other data only in relation to the themes that emerged from the afternoon tea data. This step was intended to establish the centrality of the teachers' voices. I considered the 
afternoon tea data as forming the basis of the study and have tried to avoid presenting observational data without overlaying the lens of teachers' perspectives.

However, regardless of the steps I took to disrupt the traditional structures of power in this study, and regardless of what I hope is an elevated presence of the teachers' voices in what follows, I urge the reader to be mindful of the context: this is my interpretation of what I saw. Spivak (1990) says, "We cannot but narrate, but when a narrative is constructed, something is left out" (pp. 18-19). This is not collaborative research (Giroux, 1988), nor action research (Brown \& Jones, 2001), nor educative research (Gitlin, 1990). This can be viewed only as my adulterated and personal version of reality.

When I use the terms ESOL pedagogy and language pedagogy, I include more than merely the transmission of information about functional language use and grammar. I seek to broaden constructs of ESOL pedagogy by extending understandings of this term to include the making of meanings, identities, and ideologies within language. This means that I am interested in all ESOL classroom interactions and not only those that are explicitly about language instruction in its narrowest sense. For this reason, although it could be argued that many of the events that I describe might have happened just as readily in a math classroom, a music classroom, or a social studies classroom, their relevance to this discussion is not a connection to a limited and technical understanding of language learning as simply transmission of grammar and vocabulary; rather, they are relevant because they occurred in the rich and corporeal context of an ESOL classroom. All language learning involves learning about identity, gender, and knowledge.

The stories presented in this article are simply snapshots, mere seconds out of a long and complicated year in the lives of these two teachers, and are not intended to represent the entire year. Because I believe that human identities are fragmented and sometimes contradictory, I did not seek to create cohesion out of these multiple identities, but rather to foreground the slices that were relevant to this discussion. Freire (1974) advises us to embrace the unfinishedness of the human condition. Recognizing the unfinished nature of all research, and indeed all learning, liberates us to view our individual research efforts as part of a larger ongoing and never-ending research effort.

\section{Findings: The Value of Beauty}

Negotiating a place for the body in the ESOL classroom was intricate work. The topic of students' physical appearance surfaced repeatedly during the year and was evident in a variety of contexts. In the afternoon tea discussions it appeared always, without exception, in reference to standards of beauty for female students. In theory a discussion of gendered pedagogies should explore constructions of masculinity and constructions of femininity, asking 
What does it mean to be male? What does it mean to be female? What does it mean to be both? What does it mean to be neither? However, in this analysis I discuss the gendered body only in relation to female identity, because the connection between gendered bodies and male identity was absent from the afternoon tea conversations. Although it is indisputable that male identity was being constructed in the classroom, I had made the methodological decision to privilege the afternoon tea transcriptions and to introduce data from other sources only when I could do so in the context of the teachers' voices. Connections between masculinity and the body are, therefore, not discussed here, but their absence is important and is addressed below in the implications section.

Messages about female beauty were a constant in the lives of the teachers and their ESOL students. Bourdieu (2001) suggests that the presence of bodily norms ensures that women remain on a permanent quest for the unachievable: "Continuously under the gaze of others, women are condemned constantly to experience the discrepancy between the real body to which they are bound and the ideal body towards which they endlessly strive" (p. 67). Alexandra and Katie faced the challenge of guiding their young female and male students as they tried decide how to position themselves in relation to normative definitions of female beauty. In this article I illustrate the complexity of the terrain in which the teachers were working. I problematize the place that the body occupies pedagogically, and in an effort to contribute to and extend current understandings of teaching, I describe the varying approaches taken by two teachers. However, it would be ingenuous to expect any individual study, teacher, or researcher to provide a solution to the challenging work of situating embodied identities appropriately in the classroom.

Fashioning meanings of gender in this study proved a complex and dynamic process, because Alexandra and Katie both sought to teach transformatively, and their critical perspectives contributed to the identities that their students formed. The teachers, therefore, undertook a two-pronged task: (a) guiding students' social understandings of what they considered to be normative constructions of femininity and masculinity in their new home communities, and simultaneously (b) challenging these normative constructions. This discussion centers around not actual normative constructions of gender, the meanings of which defy definition because they are so subjective and fluid, but rather around the teachers' perceptions of normative constructions. The pedagogical acts of teachers who seek to teach transformatively are a rich site in which to explore how identity, gender, and language pedagogy interact.

Both Katie and Alexandra were concerned about the place occupied in their students' minds by the concept of beauty, and both had misgivings about societal perceptions of their female students' external appearance. 
However, their concerns led them to different pedagogical intents. Katie discouraged her students from placing too great a value on female appearance, whereas Alexandra sought a revision of the definition of beauty offered by society at large.

Alexandra and Katie were analytical about the relationship between beauty and meanings of gender. Because physical appearance is often the first impression a person presents, it is tightly connected to identity, and in particular gender identity. However, the relationship between identity and the body is unclear, because meanings of being a woman or being a man, which dictate how we present our physical selves, are ambiguous. For Katie and Alexandra, part of being a woman is the quest to conform to socially determined standards of beauty. Within this theme I explore three major issues: (a) negotiating normative constructions of beauty, (b) separating individuals from their bodies in order to resist objectification, and (c) the constitution of women as percipi "being-perceived" (Bourdieu, 2001).

\section{Negotiating Norms}

The teaching practices of both teachers were affected by the normative practices that govern external appearance, particularly the appearance of women. They both challenged norms in contrasting ways. Alexandra worked consistently and analytically to identify and then critique normative standards of beauty. In talking about her young female students, she frequently mentioned their beauty, drawing specific attention to differences between what she herself termed beautiful and what she perceived to be mainstream conceptions of beauty. For example, of one student she said, "She has a beautiful nose, but it's not like Barbie's. It's pointy and it sticks out. And she has beautiful cheeks but her face is round, not long" (Afternoon tea, 11.04). In describing another student, she told me,

The girl I was talking about from Senegal. She has very beautiful onetoned skin and it's just very beautiful, it's such smooth color, you know? ... Her face is all one tone, and when she smiles ... it's just ... she's beautiful. She's just a little bit rough around the edges, you know? She talks too tough, and she wants to beat everyone up, you know? But she's so beautiful. (Conversation at school, 11.04)

She used the word but to separate her description of the students' physical characteristics from what she considered to be dominant ideas about beauty, indicating a gap between the two. She perceived long faces and Barbie's nose as conventionally beautiful. A pointy nose that sticks out, a round face, talking too tough, wanting to beat everyone up, and being rough around the edges, although not inconsistent with Alexandra's construction of beauty,

directly contradicted what this teacher perceived as a normative definition of beauty. As she highlighted the distinction between her ideas and those of 
society, she was constructing herself as a teacher who embraced heteroglossic (Bahktin, 1981) and hybrid definitions of beauty (Wong, personal communication, May 28, 2003), forms of beauty that did not conform to the main stream. She sought the same for her students because she wished to challenge the idea "that middle-school-age kids ... still want to be the magazine beautiful."

Alexandra displayed a vigilant consciousness of the power of norms and worked to reinforce the gap between social norms and her own standards. Foucault (1978) believed that the practices of "disciplinary power," an alluring and potent form of social control, are harbored in regulatory institutions, including schools, and are practiced not only by representatives of these institutions (including teachers), but by individuals passing through their prosaic daily routines. Disciplinary power derives its effectiveness by attracting humans to certain desires, norms, and identities. For example, the continued popularity of Mattel's Barbie doll among parents and girls is an example of how disciplinary power exerts itself, repeatedly underscoring the desirability of the doll's physical appearance as a bodily ideal. Teachers and school culture contribute to the shaping and reshaping of appropriate bodily norms, but individual teachers can choose to produce or subvert disciplinary power. Alexandra's position was complex. She was clearly critical of Barbie dolls, suggesting that the dolls contributed to a grand metanarrative that constructed whiteness as normative, and she explicitly sought to stimulate her students to be critical of Barbie's whiteness: "And the girls were like, well, I don't know, I like Barbie. I've always played with Barbie. And I was like well how does it feel when you don't see a black Barbie? When you don't see a Bangladeshi Barbie?"

Alexandra was pleased to note the girls indicating that they were developing broader notions about beauty, and in particular ideas about beauty that included their racial selves: "So the girls were like 'yeah, yeah, I am beautiful,"' and she perceived this change as the first step: "It was really just a beginning. It was just saying I think you're beautiful, everybody else should think you're beautiful" (Interview, 11.04).

Alexandra seeks to create possibilities for multiple meanings and interpretations of beauty. Her argument is complicated because it seems to challenge the myth of white beauty (Wolfe, 1991) without denouncing other systems of oppression, for example, the doll's unrealistic bodily proportions. However, I interpreted this discussion as one step in an incremental, concerted approach to the many-layered task of critiquing multiple norms of beauty around her. For example, at other times during the year, Alexandra expressed concern about her female students' attempts to become unreasonably thin. Early in the school year, on learning that some young women in her class were on extreme diets, she planned a unit on food that included a section on "talking about food and what is healthy and unheal- 
thy" (Interview, 10.07). She invited a counselor to talk to the female students in one class when she suspected that one might have an eating disorder. Thus she sought to discourage the girls' attempts to conform to multiple normative standards of beauty, including those pertaining to race and physical size.

\section{Separating Individuals from Their Bodies}

Like Alexandra, Katie was concerned about her students feeling pressure to conform to media-controlled definitions of female beauty. However, Katie's approach differed significantly from Alexandra's: she took exception to the value structures of students who placed too great an emphasis on appearance. Whereas Alexandra believed that the definition of beautiful should be broadened to include a greater variety of bodies, Katie sought to teach her girls to appreciate themselves apart from their physical attractiveness, their bodies. In class one day, the students were discussing their career goals:

Katie: Jennifer, what do you want to be when you grow up?

Jennifer: A doctor. No, a supermodel.

Katie: Are you sure you want to be a supermodel?

Jennifer nods.

Katie: You know, you're certainly pretty enough to be a supermodel,

but is there any other ambition that you have?

Jennifer: Maybe a doctor. No, a supermodel.

Katie: Maybe it'll change when you get older. (Field Notes, 03.21)

We discussed the incident with the other teachers at an afternoon tea, and Katie said, "This one girl, Jennifer, she's so bright, and she said that when she grows up, she wants to be a supermodel ... I didn't want to impose my beliefs on her, saying you can be so much more than a supermodel!" (Afternoon tea, 06.19).

Katie perceived supermodeling as unsuitable for an intelligent girl. She was conscious of the authority associated with her teacher's status and hesitant to abuse it, but she was similarly reluctant to support Jennifer's choice. Alexandra felt that imposing in this instance was justified, responding, "That's one I don't mind saying." At this point Alexandra was supporting Katie's criticism of modeling. Katie explained that although she had questioned Jennifer's choice, she had not sought to direct her away from it, because she concluded that the 6th-grader's ambitions would evolve as she grew up: "Because I know it'll change." Although not directly dissuading her from modeling, she stimulated her to think about alternatives. I asked Katie, "Why don't you want her to be a supermodel?" and Katie replied:

Because I don't think it takes brains to be a supermodel, and I think it places too much emphasis on a woman's looks. And I think she has a lot more talent and brains to be more ambitious than that. I just think she 
can be so much more than her looks. I want her to feel like she can do so much more than just be a pretty face.

Katie believed that talent and brains were more valuable than appearance. Alexandra noted that although it does not take "brains to be a supermodel," intelligence and modeling are not mutually exclusive: "You might need brains to survive it, though. It's a hard life." Katie elucidated on why she objected to her female students aspiring to be models: "Modeling kind of emphasizes the whole idea that women are valued for their beauty, and once other people think you're not so beautiful anymore, even if you are, it just seems very sad for me." The teacher challenged what she perceived as a social tendency to value women's physical appearance to the exclusion of other qualities, and she specifically critiqued the fleeting nature of this value system. As she had done throughout the earlier part of the school year, Alexandra valued appreciation of female physical appearance, but objected to the narrow confines of the historical definition of beauty. She expressed a preference for redefining and broadening society's definition of beauty to include multiple definitions rather than minimizing the importance of physical beauty: "Just to give you some hope, I think that's changing. I mean, supermodels are being demographed at age 50 now and pregnant and things that are not traditionally thought of as beautiful."

Katie, however, believed that an disproportionate emphasis on physical beauty would discourage students from focusing on what she perceived as more important facets of themselves: "Well, I also wanted her to recognize the importance of inner beauty and not just external beauty, and how inner beauty is so much more important." For Alexandra, physical beauty was a valuable attribute that needed a more all-inclusive definition, whereas Katie believed that physical beauty was simply overvalued socially.

Separating the girl from the body provides a sense that she can be appreciated apart from her physicality. However, the tendency toward disembodiment has been criticized. Jackson and Scott (2001) have called for the body to be socially situated and socially mediated. Realistically speaking, it is bodies that classify humans at first glance by conveying sex, age range, race, and other loaded social markers, so it might not have been practical to imagine that Jennifer could be conceptualized apart from her physical appearance. The situation that Katie faced was messy: she objected to modeling because it dissociates individuals from their bodies and then values the bodies, which results in their objectification. Katie did not challenge the dissociation itself, but rather reinforced it and sought instead to value the individual apart from her physicality.

Establishing body and mind as independent from each other creates a new tension: if an individual can be conceptualized apart from her body, then conceptualizing the body apart from the individual is a natural progression. Disembodied minds create the possibility of mindless bodies including, 
for example, models, slaves, and prostitutes. Conversely, acknowledging the physical body implies the possibility and even the necessity of disciplining the physical body into conformity, a necessity that Katie was loath to underscore.

\section{Esse as Percipi}

Masculine domination, which constitutes women as symbolic objects whose being [esse] is a being-perceived [percipi], has the effect of keeping them in a permanent state of bodily insecurity, or more precisely of symbolic dependence. They exist first and through the gaze of others, that is as welcoming, attractive, and available objects. (Bourdieu, 2001, p. 66, emphasis in original)

What responsibilities do teachers have toward their male students as they grapple with the location of female beauty in relation to gender identity? ESOL teachers face the daunting task of finding the middle ground between teaching male students to critique normative standards of beauty and appearing to seek their male students' approval for nonstandard forms of beauty. The relationship between body and identity is ambiguous, because identity is an essentially social concept. Who one is evolves in relation to others. To a limited extent every human is objectified by the gaze of others, but similarly, every human is constructed by the gaze of others. However, the normalization of certain female bodies (but not others) particularly underscores the percipi (being perceived) status of women. For example, Alexandra sought a revision of her female students' self-concepts, emphasizing that their beauty, although unconventional, was nonetheless beauty. However, she wished to teach all students, and not only girls, to think critically about media-generated images of beauty. As such she wished her male students to rewrite their definitions of beauty and to see the female students as beautiful: "the boys were just kind of taking it in. I like the co-ed setting because the boys are all after the girls, but I think that discussion, I'm hoping, is making the boys see the girls differently" (Interview, 11.04). Because the boys had sexual interest in the girls, Alexandra was concerned about how they defined female beauty in general. She therefore specifically focused on their assessment of the appearance of these female students. It was important to Alexandra that the boys see these particular girls as beautiful.

Similarly, later in the school year, when Alexandra became aware that her female students were skipping meals and developing unhealthy eating habits in order to lose weight, she invited a counselor to speak to all the girls in her class in her absence and then continued the discussion during class time. She told me, "But when they came back the next day, we talked about 
it in a co-ed setting. And I thought it was very interesting because the boys were listening" (Interview, 05.04).

This concern about the boys is a challenging problem for teachers who seek to raise the consciousness of all their students, not only the girls, without privileging the opinions of the boys. This tension draws on what de Beauvoir (1949) described as the distinction between the objective self and the subjective self. De Beauvoir believed that when girls reach puberty, they cease being the subjects of their own lives and become instead the objects of others', they "stop being and start seeming" (p. 370). Whereas once girls lived their lives for themselves, after puberty they live under the gaze of others and are focused not on how they are, but on how they appear to others. De Beauvoir's delineation may be excessively stark, but it captures how a preoccupation with the gaze of others keeps young women focused on their image and, therefore, dependent on others, in this case on their male peers. Teachers like Alexandra seek to negotiate complicated terrain. They wish to help all students to recognize and challenge the power of normative ideals of beauty. They strive to encourage their boys to be critical of social norms, but they must do so without appearing to seek approval for the appearance of their female classmates and thus contributing to the objectification of the girls.

In a conversation about appropriate dress, Alexandra asked her class why some girls wore revealing clothing. A male student responded:

"Because it looks good."

"Why do you like it?"

"Because she looks naked when she's wearing clothes like that."

Alexandra nodded at him but didn't respond. (Field Notes, 10.12)

When I asked Alexandra about this exchange, she told me, "They were being totally honest ... I asked the girls later, how do you feel when they say things like that? The girls were like, it doesn't matter to me, I don't like them" (Conversation during planning period, 10.12).

Alexandra was concerned about how the young women would be affected by the male students' attitudes toward revealing clothes. This account revealed Alexandra's female students as indicating that they could be influenced by the young men's opinions only if they "liked" the men. However, although the girls claimed to be ambivalent toward both the boys and their opinions of revealing attire, Alexandra made a connection between the boys' endorsement of sexually revealing clothes and the young women's investment in attaining these standards: "Because you know some girls go into the bathroom and change into clothes their parents wouldn't approve of. And then change back at seventh period before they get back on the bus" (Interview, 10.12). 
Alexandra believed that whether or not the girls liked the boys, the boys' reaffirmation of dominant standards of beauty influenced the girls, because most individuals wish to present bodily appearances of which others approve. Furthermore, it is important not to ignore the role of power in this dynamic: the boys' power to contribute to the construction of standards of beauty is highly legitimized because men for the most part are constructed as the primary consumers of female beauty.

\section{Discussion/Implications}

I am really asking whether women cannot begin, at last, to think through the body, to connect what has been so cruelly disorganized. (Rich, 1976, p. 284, emphasis in original)

How can ESOL teachers invite female students' physical bodies into their classrooms without also creating space for them to be objectified? Rich calls for thinking and physicality to be brought back together, referring to their division as "cruel." The split is indeed unnatural, but it has served a purpose over the years. Critically thinking teachers and educators have (usually unconsciously) supported the evolution of mind and body apart from each other, because the body's ostensible invisibility has promised to give greater visibility to intellectual selves, liberating girls from a focus on their outer appearance. Reuniting mind and body is more difficult than it sounds. It is not possible simply to pick up a needle and thread and effortlessly stitch the two back together, because their separation served a purpose in the first place: concepts of beauty keep women positioned as consumable, and the detachment of body from mind was one way to thwart that positioning.

The fact that I saw no data connecting gendered bodies to the construction of male identity is important. Male identity was indisputably being constructed in the ESOL classrooms, but its connection to male students' physical bodies was never the explicit topic of discussion at the afternoon teas. Male bodies were simply never discussed. Although representations of the male body have certainly been transformed in recent years by more objectified and sexualized media representations of male physicality, the association of women with their bodies and men with their minds has been pervasive for much longer. Bourdieu (2001) in fact claims that the female experience of the body is of the "body-for-others, constantly exposed to the objectification performed by the gaze and discourse of others" (p. 63). The implications of the binary are different for men and women, and Gallup (1988) explains that it is simultaneously harder and easier for men: "Harder because men have their masculine identity to gain by being estranged from their bodies and dominating the bodies of others. Easier because men are more able to venture into the realm of the body without being trapped there" (p. 7). 
Just as the body is often ostensibly absent from public school classrooms, it is made invisible in teacher education classes. Teachers in preparation need to experience classes and conversations in which the body is appropriately and constructively situated. This includes creating opportunities for open discussion about the complexities and dilemmas of normative bodily practices and about the range of possibilities available for the exploration, negotiation, and expression of gender identities in relation to the physical body.

\section{Conclusion}

In this article I attempt through examination of the experiences of two ESOL teachers to problematize the pedagogical location of the body and to explore how the gendered body can be mediated in classroom contexts. Both teachers were caring and felt a responsibility toward their students. Both sought to teach in ways that simultaneously responded to their students' social needs and rejected restrictive social messages about gender. One teacher sought to minimize the conceptual space occupied by the physical body in the classroom, the other to guide the body into the conversation. My intention in this study was not to identify a solution, nor to write a prescription for the dilemma of locating bodies in ESOL classrooms. Rather, I sought to explore how two thoughtful and concerned teachers negotiated the tensions before them.

This study's broader implications for research include the necessity of a complexified understanding of language learning in relation to gender identity, in relation to the context of teaching, and in relation to the texts we use in the construction of students' identities. I propose broadening constructs of language pedagogy and its relationship to students' identities through a scrutiny of how gender plays out in texts, pedagogies, and bodily practices. Understandings of the processes of teaching and learning ESOL need to be extended beyond simply the acquisition of words and usage to include ideology in recognition that teachers and students in classrooms are always learning politics and identities. If as TESOL practitioners we limit ourselves to narrow and normative constructions of ESOL classrooms, important understandings about how gender is constructed will escape our vision.

\section{The Author}

Suhanthie Motha received her doctorate from the University of Maryland College Park. Her research explores the complexity of identity, power, language, and pedagogy in the lives of ESOL teachers and students. Her work has appeared in TESOL Quarterly and Educational Practice and Theory. She teaches in the TESOL program at the University of Maryland College Park.

\section{References}

Bakhtin, M. (1981). The dialogic imagination. University of Texas Press.

Bourdieu, P. (1982). Language and symbolic power. Cambridge, MA: Harvard University Press. 
Bourdieu, P. (2001). Masculine domination. Stanford, CA: Stanford University Press.

Brown, T., \& Jones, L. (2001). Action research and postmodernism: Congruence and critique.

Philadelphia, PA: Open University Press.

Butler, J. (1990). Gender trouble. London and New York: Routledge.

Cameron, D. (Ed.). (1990). The feminist critique of language. London: Routledge.

de Beauvoir, S. (1949). The second sex. New York: Vintage.

Erlich, S. (2001). Gendering the "learner": Sexual harassment and second language acquisition.

In A. Pavlenko, A. Blackledge, I. Piller, \& M. Teutsch-Dwyer (Eds.), Multilingualism, second language learning, and gender. New York: Mouton de Gruyter.

Fine, M. (Ed.). (1992). Disruptive voices: The possibilities of feminist research. Ann Arbor, MI: University of Michigan Press.

Foucault, M. (1978). The history of sexuality. New York: Pantheon.

Foucault, M. (1981/2000). The subject and power (R. Hurley, Trans.). In J. Faubion (Ed.), Power (pp. 160-161). New York: New Press.

Friere, P. (1974). Education: The practice of freedom. London: Sheed and Ward.

Gal, S. (1978). Peasant men can't get wives: Language change and sex roles in a bilingual community. Language in Society, 7, 1-16

Gallup, J. (1988). Thinking through the body. New York: Columbia University Press.

Gee,J. (1991). Socio-cultural approaches to literacy. Annual Review of Applied Linguistics, 12, $31-48$.

Gilligan, C. (1982). In a different voice: Psychological theory and women's development. Cambridge, MA: Harvard Univrsity Press.

Gitlin, A. (1990). Teachers' voices for school change: Introduction to educative research. New York: Teachers College Press.

Giroux, H.A. (1988). Teachers as intellectuals: Toward a critical pedagogy of learning. Critical studies in education series. Granby, MA: Bergin \& Garvey.

Glaser, B., \& Strauss, A. (1967). The discovery of grounded theory: Strategies for qualitative research. Chicago, IL: Aldine,

Goldstein, T. (1997). Two languages at work: Bilingual life on the production floor. New York and Berlin: Mouton de Gruyter.

Grosz, E. (1994). Volatile bodies: Toward a corporeal feminism. Bloomington and Indianapolis, IN: Indiana University Press.

Grumet, M. (1988). Bitter milk. Women and teaching. Amherst, MA: University of Massachusetts Press.

Harding, S. (1987). Sex and scientific inquiry. Chicago, IL: University of Chicago Press.

hooks, b. (1994). Teaching to transgress: Education as the practice of freedom. New York: Routledge.

Jackson, S., \& Scott, S. (2001). Introduction. In K. Backett-Milburn \& L. McKie (Eds.), Constructing gendered bodies (pp. 1-6). Basingstoke, UK: Palgrave.

Kanpol, B., \& McLaren, P. (1995). Critical multiculturalism: Uncommon voices in a common struggle. Critical studies in education and culture series. Westport, CN: Bergin \& Garvey.

Kouritzin, S. (1999). Facelt Js of first language loss. Mahwah, NJ: Erlbaum.

Lakoff, R. (1975). Language and woman's place. New York: Harper and Row.

Lather, P. (1991). Getting smart: Feminist research and pedagogy with/in the postmodern. New York: Routledge.

Lave, J., \& Wenger, E. (1990). Situated learning: Legitimate periperal participation. Cambridge, UK: Cambridge University Press.

Morgan, B. (1998). The ESL classroom: Teaching, critical practice, and community development. Toronto, ON: University of Toronto Press.

Motha, S. (2002). I tell because I know, I know because I tell: Storied power in second language teaching. Educational Practice and Theory, 24(2), 5-21.

Norton, B. (2000). Identity and language learning: Gender, ethnicity, and educational change. Harlow, UK: Longman/Pearson Education. 
Oxford, R., \& Green, J. (1995). A closer look at learning strategies, L2 proficiency, and gender. TESOL Quarterly, 29, 261-297.

Pavlenko, A., Blackledge, A., Piller, I., \& Teutsch-Dwyer, M. (Eds.). (2001). Multilingualism, second language learning, and gender. New York: Mouton de Gruyter.

Pica, T., Young, R., \& Doughty, C. (1987). The impact of interaction on comprehension. TESOL Quarterly, 21,737-758.

Rich, A. (1976). Of woman born: Motherhood as experience and institution. New York: W.W. Norton.

Spivak, G. (1990). The post-modern condition: The end of politics? In G. Spivak \& S. Harasym (Eds.), The post-colonial critic: Interoiews, strategies, dialogues (pp. 17-34). New York: Routledge.

Strauss, A., \& Corbin, J. (1997). Grounded theory in practice. Thousand Oaks, CA: Sage.

Sunderland, J., \& Litosseliti, L. (2002). Gender identity and discourse analysis. Amsterdam and Philadelphia, PA: Benjamins.

Tharpe, R.G., \& Gallimore, R. (1988). Rousing minds to life. Cambridge, MA. Cambridge University Press.

Turner, B.S. (1984). The body and society: Explorations in social theory. Oxford, UK: Blackwell.

Van Lier, L. (2000). From input to affordance: Social-interactive learning from an ecological perspective. In J.P. Lantolf (Ed.), Sociocultural theory and second language learning: Recent advances (pp. 276-290). New York: Oxford University Press.

Vygotsky, L. (1978). Mind in society: The development of higher psychological processes. Cambridge, MA: Harvard University Press.

West, C., \& Zimmerman, D. (1983). Doing gender. In J. Lorber \& S. Farrell (Eds.), The social construction of gender. London.

Wolfe, N. (1991). The beauty myth: How images of beauty are used against women. New York: HarperCollins. 